\title{
SIGNIFICANT CHANGE OF CIRCUMSTANCES AND THE AMENDMENT OF CONTRACT
}

\section{Juhász Ágnes}

\section{INTRODUCTION}

The judgment and treatment of the greater or lesser changes in circumstances belongs to the field of contract law. Though the obligation law rules, including contract law provisions, give the dynamics of civil law, the various legal transactions and contracts to be concluded basically reflect a given time; the contractual parties' rights and duties are fixed with regard to the circumstances existing at the time of the conclusion of the contract. However, over time, changes can occur in the circumstances of the contract, which can impact on the durable contractual relationship existing between the parties, including their rights and duties, and particularly on the duty to fulfil the contract.

All legal systems have its own solution for the treatment of the essential (substantial) change of circumstance subsequent to the conclusion of the contract. Although in these cases, the contractual parties' autonomy prevail primarily, some legal system allows the judicial amendment of the contract, if the conditions of the clausula rebus sic stantibus are fulfilled ${ }^{1}$. There are other states, where the possibility to amend the contract by judicial act in case of an essential change of circumstances subsequent to the contract conclusion has only recently been recognised by the national legislation. Moreover, it is also noteworthy that these relatively new regulations bound the application of the contract amendment by judicial act to strict limits ${ }^{2}$.

It is typical that the essential change of circumstances and its effects on the contractual relationship attracted more and more attention from the legislation and the jurisprudence, when historic events having global effect occurred. It was after the World War I, when the modern

\footnotetext{
Cf. Act No. V of 2013 on the Civil Code, Art. 6:192

2 In 2016, Code Civil was amended according to the French civil law reform. The reworded text of Article 1195 determines extensive rights for the court according to the existing contractual relationships, which were seriously affected by the unforeseen circumstances. Partly in parallel with the French reform, the Romanian civil code, modelled on the Code Napoleon, had also been revised. The new code, which came into effect in 2011, regulates the judicial amendment of contract as an exceptional legal institution, under the expression 'impreviziune'.
} 
jurisprudence examined the problem thoroughly ${ }^{3,4}$. Afterwards, the Great Depression in 1929 and its effects and consequences made it clear that the changes occurred in the contractual relationship because of the essential change of circumstances, i.e. the effect of such changes on the position of the contractual parties requires particular attention.

However, another part of the national legislators failed to take any actions in spite of the recognition mentioned above and, based on various dogmatic considerations, considered the binding force of contract as priority and kept the obligation to fulfil the contract in mind. In other countries, for instance in Hungary, clausula rebus sic stantibus is declared as an exemption from the principle pacta sunt servanda.

The demand for the application of the clausula and for the regulation of the contract amendment by judicial act arose again after the global economic crisis in 2008. Notwithstanding the fact that this newer recession is not comparable to the economic crisis in 1929, the detrimental changes which occurred in the contractual relationships due to the crisis and which often broke the contractual balance, increasingly raised the need for create a solution by legislative way.

However, the answers of the different countries to the changes in circumstances after the conclusion of the contract vary widely and it is also different that the solution to be applied is based on law or it was developed by the case-law of the courts.

Hondius és Grigoleit examined the effect of the change of circumstances on the contractual relationship in the European countries and, with respect to the legislative and judicial recognition of this effect, they distinguished between open and closed legal systems ${ }^{5}$. In countries classified as open legal system (e.g. Germany, Austria, Greece, Italy, Lithuania, the Netherlands, Portugal, Spain and Sweden) unforeseen changes of circumstances are defined both in the relating

\footnotetext{
3 Oosterhuis, Janwillem: Unexpected Circumstances Arising from World War I and Its Aftermath: Open versus Closed Legal Systems, In: Erasmus Law Review, 2014/2., pp. 67-79.

4 From the relating literature see KRÜCKMANn, Paul: Clausula rebus sic stantibus, Kriegsklausel, Streikklausel, In: Archiv für die civilistische Praxis, 1918/2-3., pp. 157-481; AlmásI Antal: A gazdasági lehetetlenülés térhóditása, In: Jogtudományi Közlöny, 1922/15., pp. 113-115; SCHUSTER Rudolf: Néhány szó a gazdasági lehetetlenülés kérdéséhez, In: Jogtudományi Közlöny, 1923/1., pp. 2-4.

5 Hondius, Ewoud: Change of circumstances: the Trento project, In: CASTERMans, Alex Geert Jansen, Kasper J.O. - Knigge, Marte W. - Memelink, Pauline - Nieuwenthuis, Jacob Hans (eds.): Foreseen and unforeseen circumstances, Kluwer, Deventer, 2012, pp. 115-133; Hondius, EwoudGRIGOLEIT, Christoph: Introduction: An approach to the issues and doctrines relating to unexpected circumstances, In: Hondius, Ewoud - GRIGoleIT, Christoph (Eds.): Unexpected Circumstances in European Contract Law, Cambridge University Press, 2011, pp. 10-11.
} 
legal regulation and in the judicial practice as general exemption, upon which the contractual parties are allowed to adopt their contract to the changed circumstances.

On the contrary, in the closed legal systems (e.g. Belgium, Czech Republic, Denmark, England, France, Ireland, Scotland and Slovenia) there is no similar solution. There are several arguments to explain this. On the one hand, there are countries, where the clausula is not declared by the civil law rules. On the other hands, there are other countries, where the clausula is known in the judicial practice, but the possibility to adapt the contract to the changed circumstances has not been generally recognised.

Nevertheless, albeit its illustrative nature, the distinction between open and closed legal systems is purely theoretical and therefore it is less suitable for showing in a certain case the differences existing between the solutions applied by the various countries ${ }^{6}$.

As it was mentioned before, during the development of the private law, several legal institutions have been evolved in the laws of the various states for the treatment of the effects of the changes of circumstances on the contractual relationship ${ }^{7}$. Such an example is the theory of imprevision ('théorie de l'imprévision') in the French civil law, while the treatment of the changes in circumstances are regulated from the obligation law reform of 2002 within the rules on the collapse of the underlying basis of the transaction ('Störung des Geschäftsgrundlage') by the German civil code ${ }^{8}$.

In the Italian civil law, there are also some provisions, which deal with the effects of the change of circumstances on the contractual relationship. ${ }^{9}$ The adoption of these rules was partly due to the events occurred at the first part of the $20^{\text {th }}$ century. Moreover, the Italian civil law at that time was strongly influenced by the German private law jurisprudence, such as Windscheid's doctrine of tacit presupposition

\footnotetext{
$6 \quad$ Hondius op.cit. p. 119; Hondius, Ewoud - Grigoleit, Christoph: General comparative remarks: Converging tendencies, remaining differences and the unsolved mystery of adjustment, In: Hondius, Ewoud - Grigoleit, Christoph (Eds.): Unexpected Circumstances in European Contract Law, Cambridge University Press, 2011, pp. 643-655, pp. 643-644.

7 The various models of the treating of the changes in circumstances are comprehensively examined by Rodrigo Uribe Momberg. See MomberG, Rodrigo Uribe: The effect of a change of circumstances on the binding force of contracts. Comparative perspectives, Intersentia, Cambridge - Antwerpen - Portland, 2011.

See BGB, Art. 313.

9 C.f. Codice civile, Art. 1467-1468.
} 
('Lehre von der Voraussetzung') and the theories of Oertmann and Larenz as well ${ }^{10,11}$.

In the English law, the essential change of circumstances subsequent to the contract conclusion raises the applicability of several legal institutions, e.g. hardship, frustration of contract, impossibility and impracticability. In this context, it is to be noted that the aforementioned legal institutes appear differently in the English and in the American law. Though the solutions applied by the American law are based on the English law traditions, due to the diverse development of the law, there are now significant differences between the legal institutions to be applied and their conditions and legal effects ${ }^{12}$.

It is important to note that the legal institutions appeared in the various national civil laws have several similarities and they correspond more or less to each other. Nevertheless, they are not absolutely identical.

On the one hand, it can be explained with the systemic differences of the various states, i.e. if a given state belongs to the Anglo-Saxon or a continental legal system. On the other hand, the diverge development tendencies of the continental law system (Germanic or French way) and the dogmatic differences also explains the greater or lesser diversions of the various legal institutions ${ }^{13,14}$.

10 WINDSCHEID, Bernhard: Die Lehre des römischen Rechts von der Voraussetzung, Düsseldorf, 1850; Oertmann, Paul: Die Geschäftsgrundlage - Ein neuer Rechtsbegriff, 1921; LARENZ, Karl: Geschäftsgrundlage und Vertragserfüllung: die Bedeutung ,veränderter Umstände ” im Zivilrecht, Beck, München, 1957. The thories of Windscheid and Oertmann are reviewed in detail by Nikolett Lukács. See Lukács, Nikolett: A clausula rebus sic stantibus elvének megjelenése a német pandektisták felfogásában, In: Smuk Péter (ed.): Az állam és jog alapvető értékei, Széchenyi István Egyetem Állam- és Jogtudományi Doktori Iskola, Győr, 2010, pp. 322-326. About the in-depth assessment and comparison of the expression 'foundation of the transaction' created and used by Oertmann and Larenz see DudÁs Attila: A szerzödés célja (kauzája) az európai és a magyar jogban. A szerzödés kauzájának fogalma az európai jogelméletben, In: Acta Universitatis Szegediensis, Acta Juridica et Politica, 2012/2., pp. 87-100, p. 91.

11 The Pandectists' impact on Italian law, by the citation of the relating judicial practice, is comprehensively overviewed in the German private law literature by Christian Reiter. See ReITER, Christian: Vertrag und Geschäftsgrundlage im deutschen und italienischen Recht: Eine rechtsvergleichende Untersuchung, Mohr Siebeck, Tübingen, 2002, pp. 48-78.

12 Cf.: EISENBERG, Melvin: Impossibility, Impracticability and Frustration, In: Journal of Legal Analysis, 2009/1., 207-261. About the American approach of the doctrine see MomBERG (2011) pp. 160-184.

13 Bazil Oglindă represents another approach, when he treats the above mentioned legal institutions equal. See OGLIndă, Bazil: The Theory of Imprevision in the Context of the Economic Crisis and the New Romanian Civil Code (NCC), In: Perspectives of Business Law Journal, 2012/1., pp. 230-255, p. 250.

14 About the different legal institutions see in detail JuHÁsz, Ágnes: A szerzödésmódositás kérdésköre a magyar polgári jogban, Wolters Kluwer, Budapest, 2019, pp. 142-182. 
Although the monographic work of Hondius and Grigoleit was quite comprehensive, they paid attention only to a limited scope of European countries, while other national legislations, like Hungarian, has not been incorporated. In the following, I intend to give an overview about, how the essential change of circumstances is treated by the Hungarian contract law. Moreover, I take a brief outlook at the relating rules of the Ukrainian civil law.

\section{The tools for treating the essential change of circumstances under Hungarian contract law. The amendment of contract by court order}

The treatment of the change of circumstances occurring after the conclusion of the contract appears several times in the application of the Act No. V of 2013 on the Hungarian Civil Code (hereinafter referred as to HCC) in force. Some situations, in which the evaluation of changes are allowed, are regulated in the general part of contract law. (These are the preliminary contract, economic impossibility of performance of contract and the amendment of contract by court order.) Other situations appear within the special provisions on certain contracts like donation contract, lending agreement and deposit contract.

Since the comprehensive elaboration of all legal institutions is not possible within this study, in the following, the examination will be narrowed to the issue of the amendment of contract by court order. On the one hand, the normative requirements of the application of this legal instrument will be examined and, on the other hand, attention will be paid to the relating judicial practice as well.

According to paragraph 1 of the Article 6:192 of the HCC, either of the parties shall be entitled to request to have the contract amended by court order if in the long-term contractual relationship of the parties performing the contract under the same terms is likely to harm his relevant lawful interests in consequence of a circumstance that has occurred after the conclusion of the contract, and (a) the possibility of that change of circumstances could not have been foreseen at the time of conclusion of the contract, (b) he did not cause that change of circumstances, and (c) such change in circumstances cannot be regarded as normal business risks.

According to the article of the HCC referred above, either of the party has the right to have the contract amended by the court, but only in the case, if requirements determined by the law are fulfilled together. Among these requirements, the long-term nature of a legal relationship shall be 
highlighted. Namely, Hungarian legislator does not recognise the possibility to amend a contract by court order generally, for all contractual relationships, but allows such form of modification only in those legal relationships, which have long-term nature. Even so, the HCC in force does not provide any general guideline, when a legal relationship shall be deemed as having long-term nature. Therefore, the interpretation of the examined expression, which roots go back to the German civil law jurisprudence of the $19^{\text {th }}$ century, is possible only within the framework established by the judicial practice and the representatives of the civil law jurisprudence ${ }^{15}$.

Summing up the most important features of these contractual relationships, it shall be stated that these are performed by long-lasting or recurring services, i.e. in these legal relationships at least either of the parties are obliged to provide a certain service continuously or periodically. Nevertheless, although the time (durability) and the service of the legal relationship is essential, these elements do not constitute a decisive and exclusive aspect in the establishing of the long-term nature of a contractual relationship, but other individual aspects also shall be taken into account.

During the examination of any change of circumstance, the time dimension, i.e. the time of occurrence, is also important. As it is stated paragraph 1 of the Article 6:192 of the HCC, change of circumstance shall occur subsequent the conclusion of the contract. Moreover, the change of circumstance, upon which the amendment of the contract is to be requested by either of the contracting parties, shall be greater volume, viz. it shall be significant. Occurrence of minor changes cannot serve as a basis for the application of amendment of contract by court order.

Beyond the above mentioned requirements, HCC imposes three other conditions on the change of circumstance itself. Basically, these criteria have negative nature. The conditions drew by the HCC are the followings:

15 From the relating literature see TöRöK TAmás: Tartós jogviszony, In: Gazdaság és Jog, 2000/11., pp. 16-21; JuHász Ágnes: A polgári jogviszony tartósságának kérdéséről, In: Jogtudományi Közlöny, 2019/4., pp. 156-164. From the relating German-language academic writings on the long-term nature of a legal relationship see Oertmann, Paul: Recht der Schuldverhältnisse, Carl Heymanns Verlag, Berlin, 1910, p. 200.; Steinberger, Max: Die Verträge auf dauernde Leistungen (Dauerverträge), C.F. Bornschein's Buchdruckerei, 1910; GIERKE, Отто von: Dauernde Schuldverhältnisse. Jherings Jahrbücher für die Dogmatik des bürgerlichen Rechts, Vol. 64, 1914, pp. 355-411.; KRÜCKMANN, PAUl: Einige Bemerkungen zu den ,dauernden Schuldverhältnissen". Jherings Jahrbücher für die Dogmatik des bürgerlichen Rechts, Vol. 66, 1916, pp. 1-17.; Gansauge, Rudolf: Das Dauerschuldverhältnis (Dissertation). Leipzig, 1928; OetKer, HaRtmut: Das Dauerschuldverhältnis und seine Beendigung: Bestandsaufnahme und kritische Würdigung einer tradierten Figur der Schuldrechtsdogmatik. Mohr Siebeck, Tübingen, 1994; Gernhuber, Joachim: Das Schuldverhältnis. Mohr Siebeck, Tübingen, 1989, pp. 377-403; Doralt, Walter: Langzeitverträge. Mohr Siebeck, Tübingen, 2018, pp. 7-61. 
a) the possibility of the change of circumstances could not have been foreseen at the time of conclusion of the contract;

b) the change of circumstances was not caused by the contractual party, whose interest was injured and who requested the amendment of contract by court upon this injury of interest; and

c) such change in circumstances cannot be regarded as normal business risks.

The expression 'foreseeability' refers to the concerned party's opportunities and borders of looking into the future, which is supplied by the criterion of reasonable conduct, i.e. what can be expected of or by a person ${ }^{16}$. According to this principle, judicial practice deems a given factor as unforeseen at the time of the conclusion of the contract, when the contractual party could not foresee it even reasonable diligence was shown by him. If a factor would have been foreseeable by the party under the above mentioned conditions, the amendment of contract by court order can not be requested, since, according to paragraph 2 of Article 1:4 of the HCC, a person may not rely, in support of his claim, on an unlawful act he has committed.

Moreover, under the $\mathrm{HCC}$, it is a further requirement that the occurrence of the change of circumstance may not be reversed to the act of the party who requests the amendment of the contract by court. Otherwise, the party's act objectively excludes both the evaluation of the change in circumstances and the application of the legal consequences of such situation determined by law.

Among the criteria on the change of circumstances stated by the HCC, the interpretation of the expression 'normal business risk' is the most difficult regarding the fact that the $\mathrm{HCC}$ does not designate the borders of this expression, i.e. it is not determined by law, if a certain change of circumstance falls under or falls outside the scope of 'normal business risk'.

Similarly, no indication on the interpretation of the examined expression is given by the reasoning of the HCC, inasmuch as it only states that subject of civil law relationships shall bear the consequences of their own conduct and this principle is especially true in case of the bearing of the normal business risk.

In the course of determining the content of the expression in question, the judicial practice evolved in connection with the former civil code can provide assistance, upon which the drawing of the borders of the expression's

${ }_{16}$ Cf. HCC, Art. 1:4, para 1. 
content becomes possible ${ }^{17}$. However, regarding the length limits of the study, the relating judicial practice will not be reviewed.

Nevertheless, a general statement can be worded. On the one hand, the content of the contract existing between the parties and the risk sharing determined in this contract shall be primarily taken into account during the assessment, whether a certain change in circumstance falls under the scope of the normal business risk. On the other hand, not only the content of the contract and the risk sharing, but the activity conducted by the contractual party and the nature of the service committed by him also shall be considered ${ }^{18}$.

According to the judicial practice, the amendment of contract by court order can not be requested by the contractual party upon such a change of circumstance, which the parties should have been, by reasonable risk, taken into account ${ }^{19}$, or which was expected or foreseen by the party at the time of the conclusion of the contract and he concluded the contract knowing these, or at the time of contract conclusion he assumed the risk of the possible damages occurring subsequent the conclusion of the contract ${ }^{20}$.

Relating to the judicial practice on contractual risks, conclusions worded by Tibor Nochta are worth mentioning. According to Nochta, who compares the conclusion of a contract to the game of dice since their results are not predictable ${ }^{21}$, contractual party can not be exempted from his obligation, if he miscalculated his performance capacity or underestimated the contractual and normal business risks ${ }^{22}$.

\section{Assessment of certain changes in circumstances under the Hungarian judicial practice}

In case of the in-depth analysis of the amendment of the contract by court order based on the significant change of circumstance, not only the normative conditions determined by the HCC, but also those changes

\footnotetext{
17 Cf. judicial cases published under BH 1996. 586., BH 2013. 275., EBH 2003. 936.

18 MenYhárd Attila: A szerzódés módositása, In: Osztovits András (ed.): A Polgári Törvénykönyvröl szóló 2013. évi V. törvény és a kapcsolódó jogszabályok nagykommentárja, Vol. III, Opten Informatikai Kft., Budapest, 2014, pp. 459-468, p. 468.

19 Judicial cases published under BH 1985. 470., Decision No. Pfv.V.21.574/2015/4. of the Curia.

20 Judicial case published under BH 2005. 347.

21 Nochta Tibor: Mennyiben szerzödési kockázat a gazdasági válság?, In: Jog - Állam Politika, 2011/2., pp. 87-97, p. 87

22 Nochta (2011) p. 89.
} 
of circumstances shall be examined, in case of which the court's power to amend a contract is recognised in the judicial practice.

As a starting point it can be noted that among the cumulative criteria led down by the HCC, the non-foreseeability and the 'out of normal business risk' nature of the change of circumstances are basically the most prominent in the judicial practice.

Acts of war, economic or other kind of crises, as well as the macropolitical changes are factors, which give cause for the amendment of contract on the one hand, or, on the other hand, can be deemed in a given case as a change of circumstance which lead to the impossibility of performance of contract. From the previous factors, changes having economic nature shall be highlighted, since after the economic crisis in 2008 , these were examined countless times by courts and they served as the basis for several judgments.

In Hungary, from the end of the 1980s, but especially after the regime change in 1989, in the judgments dealing with the applicability of the amendment of contract by court order appeared a uniform and coherent approach, according to which the inflation and the change of the supply and demand conditions were treated as factors, which fall under the scope of the contractual partners' business risks. Regarding to this, the applicability of the amendment of contract by court order was not recognised in case of these changes ${ }^{23}$. By contrast, other judgment is also known, where the large inflationary impacts of the changing economic conditions and the significant increasing of the prices of materials and wages established the application of the amendment of contract by court order. As the court stated it in its reasoning, not the above mentioned factors themselves gave cause for the applicability of the amendment of contract by court, but the fact that the measure of the change of these circumstances could not be foreseen by the contractual parties at the time of the conclusion of the contract ${ }^{24}$.

As the court stated in another individual decision, although the changing of the economic environment falls under the scope of the parties' normal contractual risks, in certain cases, namely if the economic environment changed to such extent that leads to the collapse of the marked, it shall be deemed as a significant change of circumstance which the contractual parties could not have expected

\footnotetext{
${ }^{23}$ Judicial cases published under BH 1988. 80., BH 1993. 670., BH 1996. 145., Decision No. Gf.I.30.315/2010. II. of the Regional Court of Appeal of Szeged.

24 Judicial case published under BH 1995. 659.
} 
at the time of the conclusion of the contract and which they could not count on upon reasonable risk-taking ${ }^{25}$. Nevertheless, the court did not recognise the applicability of the amendment of contract by court and considered that the consequences of such changes of circumstances shall be shared by the contractual parties.

Though the judicial practice on the determination of the "normal business risk' was relatively stable, it was significantly coloured by the economic crisis which opened an entirely new era in the judicial application of the law. Mass of foreign exchange loan contracts was negatively affected by the economic crisis, due to which so many people brought action with reference to the subsequent change of circumstances and requested the amendment of contract by court order. Therefore, the question arose again, if an economic crisis shall be deemed as normal contractual risk at all, and if so, to what extent.

To answer the question, several attempts appear both in the field of the judicial practice and the jurisprudence.

Relating to the economic and business risks, Tekla Papp examined the judicial practice and concluded that the economic and financial crises are treated as contractual risks by the Hungarian courts, and they prefer the principle pacta sunt servanda instead of the application of the clausula rebus sic stantibus with an expanded meaning" 26 .

According to Nochta, economic crises undermine the contracts' supports built by the parties and therefore the focus will shift from the contract to the law. An economic crisis results in the dissolution of the contract terms; it is the reason why a growing demand for the external intervention arises $^{27}$. As he stated elsewhere, possibilities offered by the contract proved insufficient in managing situation caused by additional risks significantly above the average. Therefore, intervention by judicial or legislative manners are needed, since nobody can fairly be obliged for a sacrifice far beyond the normal contractual risk, even the service to perform under the contract became nor physically, neither legally impossible ${ }^{28}$.

25 Judicial case published under BDT 2000. 277.

26 PAPP Tekla: Gazdasági/üzleti kockázat - mint szerzödési körülmény - megitélése a magyar magánjogban és versenyjogban, In: Szalma József (ed.): Magyar Tudomány Napja a Délvidéken, Vajdasági Magyar Tudományos Társaság, Újvidék, 2013, pp. 113-132, p. 118 and PAPP Tekla: Gazdasági válság - szerzödéses viszonyok, In: Jogtudományi Közlöny, 2011/6., pp. 353-357, p. 255.

27 Nochta (2011) p. 88.

28 Nochta Tibor: A gazdasági-pénzügyi krízis válságba sodorja-e a szerzödés intézményét? - A jogalkotás, a tudomány és a jogalkalmazás válaszai, In: AuER, Ádám - PAPP, Tekla (eds.): A gazdasági világválság hatása egyes jogintézményekre Magyarországon és az Európai Unióban, Nemzeti Közszolgálati Egyetem Budapest, 2016, pp. 179-197, pp. 184-185. 
In conclusion, it can be noted that basically two main trends appear in the judicial practice on the assessment of economic changes. Minor changes fall under the scope of the contractual parties' normal business risks, which they shall count on at the time of the conclusion of their contract. However, changes having greater volume as economic changes which can not be foreseen by the highest degree of diligence showed by the parties at the time of the conclusion of the contract, do not necessarily justify the application of the principle clausula rebus sic stantibus. The fact that courts raise the economic crisis from the normal contractual risk of the parties, does not automatically mean that the possibility to amend the contract by court order or to refuse the performance of the contract is recognised ${ }^{29}$. However, it is much more typical that economic crisis is assessed as a risk factor, which goes beyond the scope of the legal institutions (i.e. refusal of contract performance and amendment of contract by court order) regulated by the HCC. Consequently, if the contractual balance has been damaged due to the economic crisis, this factor will establish the amendment of contract by legislative act.

Beyond the economic crisis and other crisis situations, there are other situations which are discussed nowadays, since they have undoubtedly impact on the contractual relationship and especially on the performance of contract.

In the legal practice, it has long been recognised that the exit of the United Kingdom from the European Union (hereinafter referred as to Brexit) is such a change of circumstance which has several impact on the performance of the existing contracts. Due to the changes in exchange rates and the potential introduction of taxes and duties, which can occur after the Brexit, the profitability of the previously concluded contracts can decrease. Moreover, the free movement of goods and services will no more prevail which can cause further difficulties in the economic life. The United Kingdom left the European Union on 31 January, 2020. Therefore, it is an essential question, if Brexit complies with the criteria of clausula rebus sic stantibus and, accordingly, can serve as a basis for refusing the performance of an existing contract, or for the amendment of the contract by court order ${ }^{30}$.

As it was mentioned above, wars and natural disasters like earthquakes or tsunamis are events, which make the performance of the contract not

\footnotetext{
29 It is confirmed by the judicial act published under BH 1992. 123.

30 The thorough elaboration of the question see JuHÁsz, Ágnes: Brexit as a frustrating event? Reflections by the doctrine of frustration of contract in English law, In: European Integration Studies, 2019/1., pp. 38-49.
} 
only more difficult, but excuses the contractual party's liability if he can not perform the contract due to these events. Such events were recently the detrimental earthquake and the subsequent tsunami in Easter Japan in 2011, or the war situation caused by the annexation of the Crimea Peninsula by the Russian Federation in $2014^{31}$.

The most recent factor, which can have impact on the performance of international contracts, is the outbreak of the novel coronavirus. The measures introduced by the Chinese authorities in order to stop the epidemic (e.g. closure of factories and logistic centres, closing of seaports and airports for indefinite time) sooner or later will make the performance of contractual obligations impossible for more and more producers and suppliers. At present, it is questionable, if the epidemic shall be deemed as a force majeure event upon which the performance of the contract can be suspended or the contract can be terminated, or it only makes the performance of the contract more difficult, i.e. it shall be deemed as a frustrating event. Although some opinions have already appeared, at present there is no univocal answer. Nevertheless, the assessment of the outbreak of the Ebola epidemic in 2014 can help the answering ${ }^{32}$.

\section{The amendment of a contract by judicial act under the Ukrainian civil law rules - A brief outlook}

\subsection{General remarks - Basic features of the Ukrainian private law}

Before the introduction of the treatment methods of the changes of circumstances and the examination of the applicability of the amendment of contract by court order under Ukrainian law, it is essential to highlight the basic features of the Ukrainian civil law regulation.

Among the lawyers dealing with comparative law, the classification of the Ukrainian legal system is problematic in itself, since there are different approaches, which sometimes completely contradict each other ${ }^{33}$. According to the most widely accepted approach, Ukrainian legal system can be ranked into the Romano-Germanic legal family. Nevertheless, it is important to note that the Ukrainian legal system shows several

\footnotetext{
31 As further reading see KoKORIN, Ilya - VAN DER WeIDE, Jeroen: Force Majeure and Unforeseen Change of Circumstances. The case of embargoes and currency fluctuations (Russian, German and FrenchApproaches), In: Russian Law Journal, 2015/3., pp. 46-82.

32 Cf. Polkinghorne, Michael - Rosenberg, Charles B.: The Ebola Epidemic and Force Majeure: Expecting the Unexpected, In: Alternatives to the High Cost of Litigation, 2014/11., pp. $165-178$.

33 On the placing of the Ukrainian law system see in detail Kharytonov, Yevhen: Forming the Contemporary Civil Law of Ukraine: Influence of Western and Eastern Traditions of Law, In: Law of Ukraine, 2012/1-2., pp. 205-232, pp. 205-206.
} 
characteristics due to the Ukrainian historical and political development on the one hand, and due to the Eastern (Soviet and Russian) and the Southern and South-Western Asian impacts, on the other hand ${ }^{34}$.

The Ukrainian civil law system is based on the Civil Code of Ukraine (hereinafter referred as to $C C U$ ), which was adopted in 2003. In parallel with the codification procedure of the $\mathrm{CCU}$, the preparation of the Economical Code of Ukraine (hereinafter referred as to ECU) took place. The ECU was also adopted in 2003. Both codes entered into force on $1^{\text {st }}$ January, $2004^{35}$.

The Ukrainian obligation law including contract law has dualistic structure because of the co-existence of the CCU and ECU. It means that contract law and expressly the contractual relationships relating to economic activity and production are subject to a dual regulation ${ }^{36},{ }^{37}$. However, the scope of the application and the determination of the subjectmatter of the codes' provisions is not precisely delimited, which, together with the uncertainty of the notion of economic contract, arise several questions. In the lack of precise defining of economic contract, there is no clear framework, which results in numerous problems from the coming into force of the codes in the field of jurisprudence and of the legal application as well ${ }^{38}$. Nevertheless, the duplication of the provisions on obligations having economic nature means merely one reason, while the differences existing between the terminology of the codes and the different, dual approach of certain legal institutions cause further difficulties ${ }^{39}$.

The roots of the codes are also different. During the elaboration of the civil law rules, participants of the codification procedure of CCU paid special attention to the provisions of CISG and of the UNIDROIT model law, while codificators of the ECU took other aspects into consideration. Partially, this is the reason, why the dualistic system of the Ukrainian civil law is strongly criticized several times. For instance, the report of the OECD suggested

34 Cf. Logush, Lyubov: Contract Law in Ukraine, In: Ansay, Tuğrul - Basedow, Jürgen (eds.): Structures of Civil and Procedural Law in: South Eastern European Countries, BWV Verlag, Berlin, 2008, pp. 65-73.

35 About the theoretical background of the codification process see DovgerT, A: Theoretical Foundations of Contemporary Codification of Civil Law of Ukraine, In: Law of Ukraine, 2012/1-2., pp. 191-204.

36 Cf. ECU, Art. 173, paragraph I.

37 About this feature of the Ukrainian private law see BIRYukov, Alexander: The Doctrine of Dualism of Private Law in the Context of Recent Codifications of Civil Law: Ukrainian Perspectives, In: Annual Survey of International \& Comparative Law, Vol. 8 (2002), Issue 1, pp. 53-78.

38 Cf. Biryukov (2002) p. 60.

39 Luts, V.: General Characteristics of Law of Contract of Ukraine, In: Law of Ukraine, 2012/5-6., pp. 119-135, p. 105. 
the Ukrainian legislator to wind up the duality of the civil law system only one year after the adoption of the $\operatorname{codes}^{40}$.

\subsection{Amendment of contract due to the significant change of circumstances}

The issue of the amendment of the contract basically arises in the context of the binding force of contract and the principle of the sanctity of contract (pacta sunt servanda). According to Zoltán Csehi, a well-known Hungarian legal scholar, drawing the line between the rigour and the primacy of the contract - the unconditional enforcement of the principle pacta sunt servanda-, and the flexible concept of contract and the possibility to amend the contract by a judicial act, always depends on the given legal culture, traditions and the economic and social system of a certain state ${ }^{41}$.

In the Ukrainian private law, freedom of contract appears as a basic principle of contract law, which is expressly declared in Article 627 of the CCU. ${ }^{42}$ The freedom of contract implies several dimensions, namely the freedom of contract conclusion and the choice of the contracting partner on the one hand, and the freedom to determine the content of the contract, on the other hand ${ }^{43}$. However, as Luts noted, the content of the parties' contractual freedom shall be treated in much wider sense, since besides the above mentioned elements, it also includes the parties' possibility to change, terminate or prolong the validity of their contract ${ }^{44}$. Consequently, contractual parties have the rights to make changes in their contractual relationship. Nevertheless, as Hoffmann highlights in his study, the grounds for the amendment the agreements under Ukrainian contract law differ from the solutions of central European legal systems ${ }^{45}$. It is partially due to the co-existence of the CCU and ECU, since both of them contain provisions on the amendment of agreements.

${ }_{40}$ Legal issues with regard to business operations and investment in Ukraine (OECD report), 2004, p. 9.

41 CSEHI, Zoltán: Az egyoldalú szerződésmódositás általános kérdései. In: CSEHI, Zoltán Koltay, András - Landi, Balázs - Pogácsás, Anett (eds.): (L)ex Cathedra et Praxis: Ünnepi kötet Lábady Tamás 70. születésnapja alkalmából. Budapest, Pázmány Press, 2014, pp. 79-112, p. 91.

42 Logush (2009) p. 69.

43 Cf. Bodnar, T.: Principles of Contract Law in Ukraine, In: Law of Ukraine, 2012/5-6., pp. 114-126, p. 116-117.

44 Luts, V.: Phenomenon of a Contract in Civil Law, In: Приватне право і підприємництво [Private Law and Business], 2016/16., pp. 50-55, p. 51

45 Hoffmann, Thomas: Europeanisation of Private Law in Ukraine: Comparisons in the Field of Law of Obligations, In: Kerikmäe, Tanel - Chоснia, Archil (eds.): Political and Legal Perspectives of the EU Eastern Partnership Policy, Springer, Cham, 2016, pp. 181-196, p. 193. 
The CCU, similarly to the HCC, regulates, in detail, how the effects of the significant circumstances occurring after the conclusion of contract shall be treated in a contractual relationship.

Article 652 of $C C U$ recognises the possibility to amend or cancel a contract in case of the significant change of circumstances.

According to paragraph I of Article 652 of CCU, if the circumstances existed at the time of the conclusion of the contract significantly changed afterwards, contractual parties can amend or cancel their contract by consent, unless they otherwise agreed or the nature of the obligation implies otherwise.

It is to be noted that the relationship between the amendment and the cancellation of the contract is not declared by the CCU. Namely, the Ukrainian legislator does not create a hierarchy between the above mentioned legal possibilities, but leaves the contracting parties free to decide, bearing in mind their personal interests, either to maintain or terminate their contractual relationship.

In contrast to the provisions of the Hungarian code, Ukrainian legislator determines, when a change of circumstance shall be deemed as significant. On the basis of the text of the above referred Article of $\mathrm{CCU}$, a change of circumstances shall be deemed as significant, if the extent of change could not be foreseen by either of the parties, and, in case of such circumstances parties would not conclude their contract or would conclude it under different conditions.

According to the text of the CCU, it is clear that the Ukrainian legislator assigns primarily the contractual parties to treat the effects of the change of circumstances on their contractual relationship, i.e. their autonomy of will ensured by the law at the time of contract conclusion extends to the modification in the content of the contract, as well. Nevertheless, if parties can not agree on the treatment of the impact of the change of circumstances, i.e. they can not agree on the adaptation of the contract to the changed circumstances (amendment) or on the termination of the contract, the application of another legal institution appears.

The amendment of the contract by court order, ensured by the CCU, is an exceptional tool for treating the impacts of a significant changes of circumstances, which can be applied only upon the expressed request of either of the contractual parties.

It is important to note that the amendment of the contract by court order based on the significant change of circumstance and initiated by either of the parties, is allowed only in individual situations, when the termination 
of the contract would be contrary to the public interests, or, the parties' loss arising due to the termination of contract would substantially exceed the expenses required for the fulfilment of the contract under the conditions amended by the court.

Although the amendment and the termination of contract appear at first sight as alternatives for the treatment of the significant change of circumstances, in the lack of consent, termination of contract remains the only way for the parties. However, it shall be added, that the legal consequences of the termination can not be determined by the parties, but the court, upon the request of either of the parties. The court bases its decision on the fair distribution of costs arising due to the fulfilment of contract ${ }^{46}$.

It is also essential that even the above mentioned condition (i.e. the lack of the parties' consent on the amendment or termination) fulfils, amendment of contract by court order can only be applied, if further criteria determined in paragraph II of Article 652 of CCU simultaneously fulfil. Accordingly, a contract can be amended by court order upon the request of either of the contracting parties, if

a) at the time of the conclusion of their contract parties could not count on the such change of circumstances;

b) change of circumstances is due to the conditions which the concerned party failed to remove after their emergence in spite of all his diligence and prudence;

c) fulfilment of the contract would disturb the balance of the parties' property interests and would deprive the concerned party of everything he expected to get at the time of the conclusion of the contract; and

d) the essence of the contract or business practices do not result in the risk of the circumstances' change to be borne by the concerned party.

The above reviewed rules and criteria prevail, if an agreement falls only under the scope of the CCU. However, due to the dualistic regulative structure of the Ukrainian civil law, in case of economic agreements, not only the provisions of the CCU shall be taken into consideration, but attention shall be paid to the provisions of the ECU as well. Nevertheless, because of the uncertain borders of the notion of economic agreement, it is not always obvious if only the relating rules of CCU or of both codes shall be applied.

Article 188 of ECU determines the procedure for the amendment and the termination of economic agreements. Provisions included in this

${ }^{46}$ Cf. CCU, Art. 652, paragraph III. 
article are basically complete the provisions of the CCU on the amendment of contract. As it is stated, the unilateral amendment of economic agreements is prohibited unless the contractual parties or the law provide otherwise. The party initiating the amendment of the contract is obliged to notify about his intention the other party, who shall react about his decision in twenty days after the reception of the notification. Afterwards, the fate of contract depends on the parties' agreement on the amendment, or, if they fail to agree, the interested party has the right to pass the dispute to the court. If the contract is amended by court order, the parties' agreement shall be regarded as amended on the day when the court order becomes final, unless other effective date is provisioned by court decision.

\section{CONCLUSIONS}

In closing, some concluding remarks can be drafted. First of all, it can be stated that treatment methods of significant (elsewhere essential) changes in circumstances appear both in the Hungarian and the Ukrainian civil law. It is also a common feature that both regulation recognises the amendment of the contract by court order in case of such events and criteria determined by the HCC and CCU show similarities as well (e.g. the unforeseeability of the change of circumstance).

Nevertheless, differences between the application of the amendment of contract by court order under the Hungarian and Ukrainian law also can be shown.

In Hungarian law, amendment of contract b court order appears as a single legal institution, which is open to the contractual parties, if their relationship has long-term nature and the conditions set by paragraph 1 of Article 6:192 of the HCC fulfil.

In Ukrainian law, similarly to the Hungarian rules, amendment of contract by court order appears as an exceptional tool for treating the impacts of a significant change of circumstances. However, the criteria for the application of the legal institution diverge, since, for instance, the disturbance of the parties' property interest due to the fulfilment of the contract by such change is also expected.

After examining the relationship between the amendment of contract by the parties' consent and the amendment of contract by court order, it can be stated that the intention of the parties is primary in the case of amendment of contract in both regulation, regarding the contractual parties' freedom of contract. In the lack of consent, contractual parties may request the amendment of the contract by court order. However, CCU contains 
a special rule, which is unknown in the Hungarian civil law. According to paragraph 4 of Article 652 of CCU, amendment of the contract by court order, when termination of the agreement contradicts the public interests, or, the parties' loss arising due to the termination of contract would substantially exceed the expenses required for the fulfilment of the contract under the conditions amended by the court.

\section{SUMMARY}

The main topic of the study is to introduce, how the significant (elsewhere essential) changes in circumstances are treated by the Hungarian civil law, which are the basic criteria for the application of the legal institution 'amendment of contract by court order'. After the general overview of the topic, relating Hungarian provisions are examined in detail. In the course of this in-depth examination, previous and current judicial practice is also reviewed, upon which the scope of those events, in case of which the Hungarian judicial practice recognise the applicability of the amendment of contract by court order, can be drafted. In closing, the study contains a short outlook on the Ukrainian civil law and examine the applicability of the same legal institution, i.e. the amendment of contract by court order in light of the Ukrainian provisions.

\section{REFERENCES}

1. Almási Antal: A gazdasági lehetetlenülés térhóditása, In: Jogtudományi Közlöny, 1922/15, pp. 113-115.

2. Biryukov, Alexander: The Doctrine of Dualism of Private Law in the Context of Recent Codifications of Civil Law: Ukrainian Perspectives, In: Annual Survey of International \& Comparative Law, Vol. 8 (2002), Issue 1, pp. 53-78.

3. Bodnar, T.: Principles of Contract Law in Ukraine, In: Law of Ukraine, 2012/5-6., pp. 114-126.

4. CsenI, Zoltán: Az egyoldalú szerződésmódositás általános kérdései. In: Csehi, Zoltán - Koltay, András - Landi, Balázs - Pogácsás, Anett (eds.): (L)ex Cathedra et Praxis: Ünnepi kötet Lábady Tamás 70. születésnapja alkalmából. Budapest, Pázmány Press, 2014, pp. 79-112.

5. Doralt, Walter: Langzeitverträge. Mohr Siebeck, Tübingen, 2018

6. Dovgert, A: Theoretical Foundations of Contemporary Codification of Civil Law of Ukraine, In: Law of Ukraine, 2012/1-2., pp. 191-204.

7. DudÁs Attila: A szerződés célja (kauzája) az európai és a magyar jogban. A szerződés kauzájának fogalma az európai jogelméletben, In: Acta Universitatis Szegediensis, Acta Juridica et Politica, 2012/2., pp. 87-100. 
8. EISEnberg, Melvin: Impossibility, Impracticability and Frustration, In: Journal of Legal Analysis, 2009/1., pp. 207-261.

9. Gansauge, Rudolf: Das Dauerschuldverhältnis (Dissertation). Leipzig, 1928.

10. Gernhuber, JoAChim: Das Schuldverhältnis. Mohr Siebeck, Tübingen, 1989, pp. 377-403.

11. Gierke, Оtтo von: Dauernde Schuldverhältnisse. Jherings Jahrbücher für die Dogmatik des bürgerlichen Rechts, Vol. 64, 1914, pp. 355-411.

12. Hoffmann, Thomas: Europeanisation of Private Law in Ukraine: Comparisons in the Field of Law of Obligations, In: KerIKMÄE, Tanel Chochia, Archil (eds.): Political and Legal Perspectives of the EU Eastern Partnership Policy, Springer, Cham, 2016, pp. 181-196.

13. Hondius, Ewoud: Change of circumstances: the Trento project, In: Castermans, Alex Geert - Jansen, Kasper J.O. - Knigge, Marte W. Memelink, Pauline - Nieuwenthuis, Jacob Hans (eds.): Foreseen and unforeseen circumstances, Kluwer, Deventer, 2012, pp. 115-133.

14. Hondius, Ewoud - GrigoleIT, Christoph: Introduction: An approach to the issues and doctrines relating to unexpected circumstances, In: Hondius, Ewoud - GrigoleIt, Christoph (Eds.): Unexpected Circumstances in European Contract Law, Cambridge University Press, 2011, pp. 10-11.

15. JuHÁsz, Ágnes: Brexit as a frustrating event? - Reflections by the doctrine of frustration of contract in English law, In: European Integration Studies, 2019/1., pp. 38-49.

16. JuHász Ágnes: A polgári jogviszony tartósságának kérdéséről, In: Jogtudományi Közlöny, 2019/4., pp. 156-164.

17. JuHÁsz, Ágnes: A szerződésmódositás kérdésköre a magyar polgári jogban, Wolters Kluwer, Budapest, 2019, pp. 142-182.

18. Kharytonov, Yevhen: Forming the Contemporary Civil Law of Ukraine: Influence of Western and Eastern Traditions of Law, In: Law of Ukraine, 2012/1-2, pp. 205-232.

19. KoKORIn, Ilya - VAN DER WeIDE, Jeroen: Force Majeure and Unforeseen Change of Circumstances. The case of embargoes and currency fluctuations (Russian, German and FrenchApproaches), In: Russian Law Journal, 2015/3., pp. $46-82$.

20. KrüCKmann, Paul: Clausula rebus sic stantibus, Kriegsklausel, Streikklausel, In: Archiv für die civilistische Praxis, 1918/2-3., pp. 157-481.

21. Krückmann, PaUl: Einige Bemerkungen zu den ,dauernden Schuldverhältnissen". Jherings Jahrbücher für die Dogmatik des bürgerlichen Rechts, Vol. 66, 1916, pp. 1-17.

22. LARENZ, Karl: Geschäftsgrundlage und Vertragserfüllung: die Bedeutung ,veränderter Umstände” im Zivilrecht, Beck, München, 1957. 
23. Logush, Lyubov: Contract Lawin Ukraine, In:Ansay, Tuğrul-BASEDow, Jürgen (eds.): Structures of Civil and Procedural Law in: South Eastern European Countries, BWV Verlag, Berlin, 2008, pp. 65-73.

24. LukÁcs, Nikolett: A clausula rebus sic stantibus elvének megjelenése a német pandektisták felfogásában, In: SMuk Péter (ed.): Az állam és jog alapvető értékei, Széchenyi István Egyetem Állam- és Jogtudományi Doktori Iskola, Győr, 2010, pp. 322-326.

25. LuTs, V.: General Characteristics of Law of Contract of Ukraine, In: Law of Ukraine, 2012/5-6, pp. 119-135.

26. Luts, V.: Phenomenon of a Contract in Civil Law, In: Приватне право і підприємництво [Private Law and Business], 2016/16, pp. 50-55.

27. MenYhÁrd Attila: A szerzödés módositása, In: Osztovits András (ed.): A Polgári Törvénykönyvről szóló 2013. évi V. törvény és a kapcsolódó jogszabályok nagykommentárja, Vol. III, Opten Informatikai Kft., Budapest, 2014, pp. 459-468.

28. MOMBERG, Rodrigo Uribe: The effect of a change of circumstances on the binding force of contracts. Comparative perspectives, Intersentia, Cambridge - Antwerpen - Portland, 2011.

29. NochtA Tibor: A gazdasági-pénzügyi krízis válságba sodorja-e a szerződés intézményét? - A jogalkotás, a tudomány és a jogalkalmazás válaszai, In: AuER, Ádám - PAPP, Tekla (eds.): A gazdasági világválság hatása egyes jogintézményekre Magyarországon és az Európai Unióban, Nemzeti Közszolgálati Egyetem Budapest, 2016, pp. 179-197.

30. Nochta Tibor: Mennyiben szerzödési kockázat a gazdasági válság?, In: Jog - Állam - Politika, 2011/2., pp. 87-97.

31. Oertmann, Paul: Die Geschäftsgrundlage - Ein neuer Rechtsbegriff, 1921.

32. Oertmann, Paul: Recht der Schuldverhältnisse, Carl Heymanns Verlag, Berlin, 1910, p. 200.; STEINBERGER, Max: Die Verträge auf dauernde Leistungen (Dauerverträge), C.F. Bornschein's Buchdruckerei, 1910.

33. OetKer, HaRtmut: Das Dauerschuldverhältnis und seine Beendigung: Bestandsaufnahme und kritische Würdigung einer tradierten Figur der Schuldrechtsdogmatik. Mohr Siebeck, Tübingen, 1994.

34. OGLINDĂ, Bazil: The Theory of Imprevision in the Context of the Economic Crisis and the New Romanian Civil Code (NCC), In: Perspectives of Business Law Journal, 2012/1., pp. 230-255.

35. OosTERHUIS, Janwillem: Unexpected Circumstances Arising from World War I and Its Aftermath: Open versus Closed Legal Systems, In: Erasmus Law Review, 2014/2., pp. 67-79.

36. PAPP Tekla: Gazdasági/üzleti kockázat - mint szerzödési körülmény megitélése a magyar magánjogban és versenyjogban, In: Szalma József (ed.): 
Magyar Tudomány Napja a Délvidéken, Vajdasági Magyar Tudományos Társaság, Újvidék, 2013, pp. 113-132.

37. PAPP Tekla: Gazdasági válság - szerzödéses viszonyok, In: Jogtudományi Közlöny, 2011/6., pp. 353-357.

38. Polkinghorne, Michael - Rosenberg, Charles B.: The Ebola Epidemic and Force Majeure: Expecting the Unexpected, In: Alternatives to the High Cost of Litigation, 2014/11., pp. 165-178.

39. ReITER, Christian: Vertrag und Geschäftsgrundlage im deutschen und italienischen Recht: Eine rechtsvergleichende Untersuchung, Mohr Siebeck, Tübingen, 2002, pp. 48-78.

40. SCHUSTER Rudolf: Néhány szó a gazdasági lehetetlenülés kérdéséhez, In: Jogtudományi Közlöny, 1923/1., pp. 2-4.

41. TöвÖK TAмÁs: Tartós jogviszony, In: Gazdaság és Jog, 2000/11., pp. 16-21.

42. WindSCHEID, Bernhard: Die Lehre des römischen Rechts von der Voraussetzung, Düsseldorf, 1850.

\section{Information about author: \\ Dr. Juhász Ágnes, PhD Department for Civil Law Faculty of Law University of Miskolc, Hungary}

DOI https://doi.org/10.30525/978-9934-588-43-3/1.5 